\title{
Mutation analysis of PMP22 in Slovak patients with Charcot-Marie-Tooth disease and hereditary neuropathy with liability to pressure palsies
}

\author{
Peter Resko ${ }^{1}$, Jan Radvansky², Zuzana Odnogova ${ }^{1}$, Marian Baldovic ${ }^{1}$, Gabriel Minarik ${ }^{1,3}$, \\ Helena Polakova ${ }^{2}$, Roland Palffy ${ }^{4}$ and Ludevit Kadasi ${ }^{1,2}$ \\ ${ }^{1}$ Department of Molecular Biology, Faculty of Natural Sciences, Comenius University, Bratislava, Slovak Republic \\ ${ }^{2}$ Institute of Molecular Physiology and Genetics, Slovak Academy of Sciences, Bratislava, Slovak Republic \\ ${ }^{3}$ Institute of Molecular Biomedicine, Faculty of Medicine, Comenius University, Bratislava, Slovak Republic \\ ${ }^{4} 2^{\text {nd }}$ Institute of Pathophysiology, Faculty of Medicine, Comenius University, Bratislava, Slovak Republic
}

\begin{abstract}
Charcot-Marie-Tooth disease (CMT) and related peripheral neuropathies are the most commonly inherited neurological disorders in humans, characterized by clinical and genetic heterogeneity. The most prevalent clinical entities belonging to this group of disorders are CMT type 1A (CMT1A) and hereditary neuropathy with liability to pressure palsies (HNPP). CMT1A and HNPP are predominantly caused by a $1.5 \mathrm{Mb}$ duplication and deletion in the chromosomal region $17 \mathrm{p} 11.2$, respectively, and less frequently by other mutations in the peripheral myelin protein 22 (PMP22) gene. Despite being relatively common diseases, they haven't been previously studied in the Slovak population. Therefore, the aim of this study was to identify the spectrum and frequency of PMP22 mutations in the Slovak population by screening 119 families with CMT and 2 families with HNPP for causative mutations in this gene.

The copy number determination of PMP22 resulted in the detection of CMT1A duplication in 40 families and the detection of HNPP deletion in 7 families, 6 of which were originally diagnosed as CMT. Consequent mutation screening of families without duplication or deletion using dHPLC and sequencing identified 6 single base changes ( 3 unpublished to date), from which only c.327C $>\mathrm{A}$ (Cys109X) present in one family was provably causative.

These results confirm the leading role of PMP22 mutation analysis in the differential diagnosis of CMT and show that the spectrum and frequency of PMP22 mutations in the Slovak population is comparable to that seen in the global population.
\end{abstract}

Key words: Charcot-Marie-Tooth disease — Deletion - Duplication - Hereditary neuropathy with liability to pressure palsies - Mutation - Peripheral myelin protein 22

\begin{abstract}
Abbreviations: CHN, congenital hypomyelinating neuropathy; CMT, Charchot-Marie-Tooth disease; CMT1, demyelinating CMT with autosomal dominant inheritance; CMT2, axonal CMT with autosomal dominant inheritance; $\mathrm{C}_{\mathrm{T}}$, threshold cycle; DSS, Dejerine-Sottas syndrome; HNPP, hereditary neuropathy with liability to pressure palsies; HSA, human serum albumin; NCV, nerve conduction velocity; PMP22, peripheral myelin protein 22; PMP22, peripheral myelin protein 22 gene; PNS, peripheral nervous system.
\end{abstract}

Correspondence to: Peter Resko, Department of Molecular Biology, Faculty of Natural Sciences, Comenius University, Mlynska dolina pavilion B2-210, 84215 Bratislava, Slovak Republic

E-mail: resko.peter@gmail.com 


\section{Introduction}

Charcot-Marie-Tooth disease (CMT) and related inherited peripheral neuropathies represent a clinically and genetically heterogeneous group of disorders affecting the peripheral nervous system (PNS). CMT in general is the most commonly inherited peripheral neuropathy, with an estimated international average prevalence of 17-40 per 100000 individuals (Skre 1974; Barisic et al. 2008). It is found world wide in people of all races and ethnic groups except for some rare subtypes (Emery 1991). CMT is characterized by a slowly progressive weakening and atrophy of distal muscles and distal sensory impairment, which usually starts in the lower limbs and progresses to the upper limbs in advanced stages of the disease. Additional symptoms are skeletal deformities and decreased or absent tendon reflexes (Lupski et al. 1991).

CMT is commonly divided into three main groups based on the electrophysiological findings in peripheral nerves of patients. According to this classification, markedly slowed motor nerve conduction velocity (NCV) (lower than $38 \mathrm{~m} / \mathrm{s}$ ) is typical of demyelinating neuropathies, while normal or slightly reduced motor NCV (higher than $38 \mathrm{~m} / \mathrm{s}$ ) is typical of axonal neuropathies (Harding and Thomas 1980). The third group consists of CMT types with non-homogeneous electrophysiological findings, where NCVs can be either above or below the $38 \mathrm{~m} / \mathrm{s}$ criterion value in different patients from a family and is called intermediate CMT (Nicholson and Myers 2006). The classification of CMT combines these basic criteria with inheritance pattern and genetic background to further subdivide these main groups, and comprises more than 40 clinical entities.

The most common subtype responsible for about $43 \%$ of all CMT cases is CMT type 1A (CMT1A), a demyelinating neuropathy with autosomal dominant inheritance (Szigeti et al. 2006). CMT1A patients show general symptoms of CMT as well as symptoms specific for demyelinating neuropathies, which are decreased NCV and structures called onion-bulbs visible on sural nerve biopsies, arising due to demyelination and remyelination of axons (Lupski et al. 1991). The clinical presentation of this non-lethal disease has a broad range, causing mild to moderate disability in patients. The variable severity of symptoms is presumably caused by different genetic background of patients; however, there is evidence that non-genetic factors may also be involved (Garcia et al. 1995).

Hereditary neuropathy with liability to pressure palsies (HNPP) is a CMT related inherited peripheral neuropathy with a prevalence of 16 cases per 100000 individuals (Meretoja et al. 1997). HNPP is an autosomal dominant disorder with marked phenotypic variability. The predominant "classic phenotype" is characterized by recurrent episodes of nerve palsy resulting in mononeuropathy. Palsies are caused by relatively minor compression or trauma to superficial nerves leading to numbness, muscle weakness and atrophy (Verhagen et al. 1993; Gouide et al. 1995). In the majority of cases patients recover from palsies completely, however, repeated attacks can prevent full reversal, and with aging, patients frequently develop a largely symmetric polyneuropathy that mimics CMT1. This can easily lead to the establishment of wrong diagnosis (Felice et al. 1994). Additional presenting phenotypes are acute brachial paralysis, confluent mononeuropathy multiplex and the disputed category of oligosymptomatic patients (Pareyson et al. 1996; Kumar et al. 1999). Electrophysiological findings in HNPP patients are more uniform than their clinical features and include mildly slowed NCV, increased distal motor latencies and conduction blocks ( $\mathrm{Li}$ et al. 2002). Sural biopsy findings of compression sites often show characteristic sausage like thickenings of the myelin sheath called "tomaculae" along with the signs of demyelination (Verhagen et al. 1993; Gouide et al. 1995).

CMT1A and HNPP are caused by different mutations of the gene encoding for the peripheral myelin protein 22 (PMP22). The major cause of CMT1A and HNPP is an unequal meiotic crossing-over event in the region 17p11.2-p12 encompassing PMP22. The consequent chromosomes carry a $1.5 \mathrm{Mb}$ duplication and deletion, respectively (Raeymaekers et al. 1991; Chance et al. 1993). Owing to the dosage sensitivity of peripheral myelin protein 22 (PMP22), not only point mutations in its gene, but also altered gene copy number leads to peripheral neuropathy (Saifi et al. 2003). Thus three copies of PMP22 cause CMT1A, only one copy causes HNPP and other mutations in the gene give rise to CMT1A, CMT1E (autosomal dominant inherited demyelinating CMT with hearing loss), HNPP, Dejerine-Sottas syndrome (DSS), congenital hypomyelinating neuropathy (CHN) or CMT type 2 (axonal CMT with autosomal dominant inheritance) (Fig. 1).

The PMP22 gene is highly expressed by myelinating Schwann cells of the PNS, but expression in other tissues such as the brain, intestine, lung and heart have also been reported (Baechner et al. 1995). Interestingly, despite its pleiotropic expression, the pathogenic effects of either dosage differences or other mutations in PMP22 seem to be restricted to the PNS (Nelis et al. 1999). The gene encodes a major structural membrane protein of the compact myelin, where it comprises $2-5 \%$ of the total protein content (Snipes et al. 1992). Although PMP22 is known to be involved in the regulation of myelin thickness and stability and in the maintenance of the myelin sheath (D'Urso and Müller 1991) its exact function still remains elusive.

Molecular genetic studies of CMT have been performed in numerous populations, but not yet in the Slovak population. Therefore, the aim of our study was to estimate the frequencies of CMT1A duplication, HNPP deletion and 

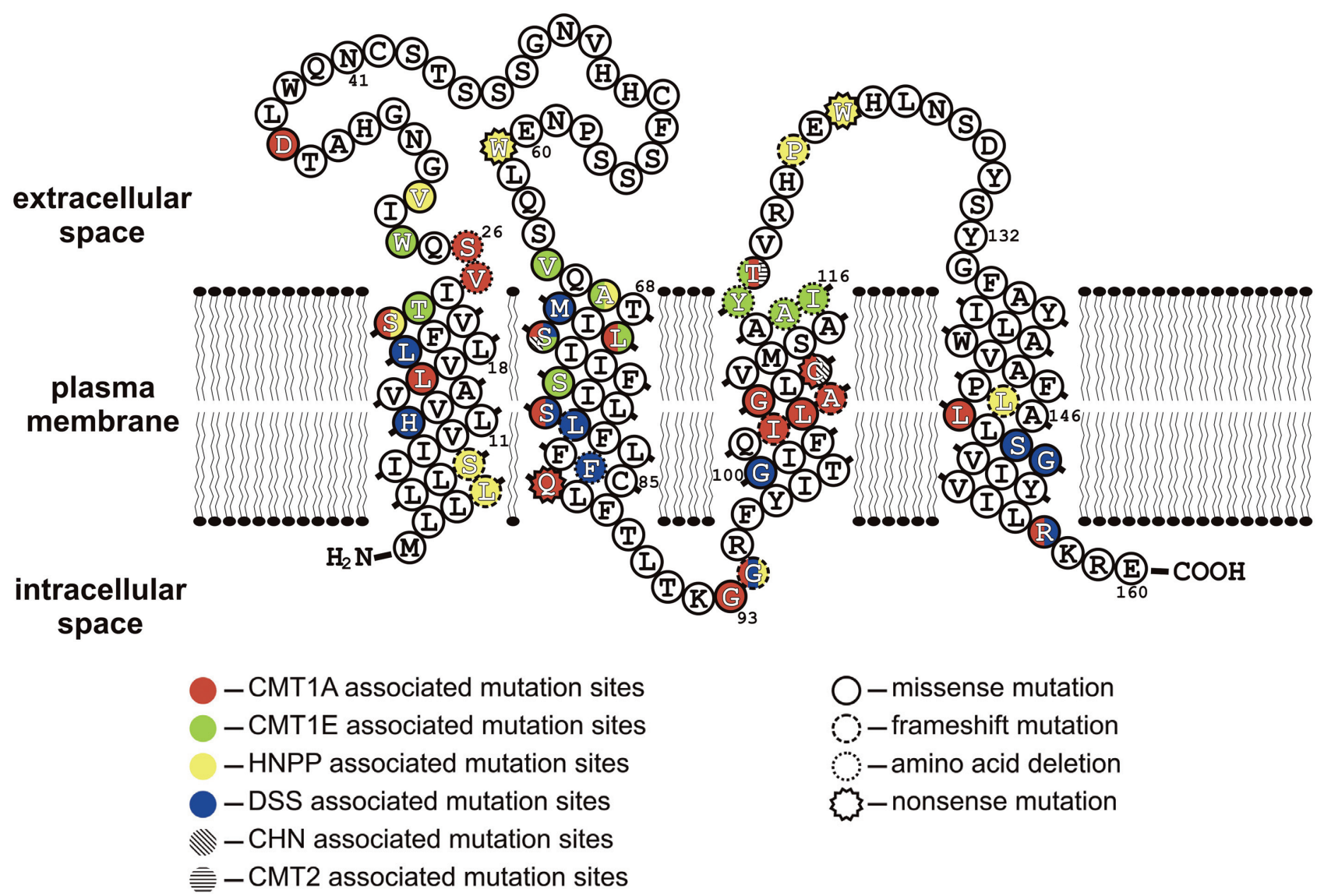

Figure 1. Amino acid sequence and putative secondary structure of PMP22 in the plasma membrane, with indicated sites of point and microindel mutations that cause peripheral neuropathy. At some positions, different mutations of the same amino acid can lead to variant phenotypes, whereas there are also cases when a specific mutation can cause variant phenotypes in different families. For example: insertion c.281_282insG (Gly94fs) is connected with HNPP, whereas a deletion affecting the codon of the same amino acid c.281delG (Gly94fs) is connected with both CMT1 and DSS. This figure is a modification of an illustration found in Sanders et al. (2001), updated by all PMP22 point and indel mutations except splice site mutations found in the Inherited Peripheral Neuropathies Mutation Database (last update 17 February 2011). CMT1E, autosomal dominant inherited demyelinating CMT with hearing loss.

PMP22 point mutations in Slovak families with CMT and contribute to the population genetic data about CMT collected so far.

\section{Materials and Methods}

\section{Patients}

For diagnostic purposes and in order to study the underlying mutations, blood samples were collected from Slovak CMT and HNPP patients since 1989. Diagnosis of patients was based on the presence of clinical symptoms. Typically, evidence of slowly progressing motor and sensory neuropathy and characteristic foot deformities in CMT, palsy/palsies at common compression sites, mononeuropathy with both motor and sensory involvement and foot deformities in HNPP. Diagnosis was confirmed by positive family history (if available) and/or by electrophysiological examination and/or in some cases by sural nerve biopsy. Patients were diagnosed in hospitals from all over the country in a time period of over 20 years. The cooperating hospitals didn't use uniform criteria for differential diagnosis of demyelinating and axonal neuropathy, in addition the applied criteria might have changed since 1989 even within one hospital. Therefore we chose not to distinguish between patients with indicated demyelinating, axonal or unspecified neuropathy and included them all in the present study. Our sample set comprised 276 DNA samples from 119 unrelated CMT families and 2 unrelated HNPP families. Informed consent regarding genetic testing was obtained from all patients and family members. Genomic DNA of the participants was 
isolated from peripheral blood either by phenol-chloroform extraction using a modified procedure of Kunkel et al. (1977) or by Puregene ${ }^{\mathrm{TM}}$ DNA Purification Kit (Qiagen).

The CMT1A duplication was formerly identified in 11 samples by STR-PCR evaluation of the marker RM11-GT (locus D17S122). Additional two samples with confirmed duplication and 2 samples with confirmed deletion were kindly provided by Dr. Seeman (University Hospital Motol, Charles University, Prague, Czech Republic). These samples were used in the validation experiments of the PMP22 copy number determination by real time PCR.

\section{Real time PCR}

Primers and TaqMan probes were newly designed using Primer3 software and purchased from Sigma-Aldrich. Primers and TaqMan probes for PMP22 exon 4 and $\mathrm{Hu}-$ man Serum Albumin (HSA) exon 12 were chosen for target and reference gene detection, respectively (oligonucleotide sequences and fluorescent labels are listed in Table 1). The TaqMan assay was carried out in a multiplex fashion in quadruplicates for each sample in 96-well optical plates (Applied Biosystems) in a final volume of $15 \mu \mathrm{l}$. The reaction mixture contained: $10 \mathrm{mM}$ Tris- $\mathrm{HCl}(\mathrm{pH}$ 9.5), $5 \mathrm{mM}$ $\mathrm{MgCl}_{2}, 1.5 \mathrm{mM} \mathrm{KCl}, 0.17 \mathrm{~g} / \mathrm{l} \mathrm{BSA}$ (bovine serum albumin), $0.1 \%$ Triton X-100, $400 \mu \mathrm{M}$ of each dNTP (GeneCraft), $1 \times$ ROX (Finnzymes), 0.6 U BioThermAB Hot Start Taq DNA Polymerase (GeneCraft), $300 \mathrm{nM}$ PMP22 forward and reverse primers, $1200 \mathrm{nM}$ HSA forward and reverse primers, 100 nM PMP22 TaqMan probe, 400 nM HSA TaqMan

Table 1. Sequences and modifications of oligonucleotides used in this study

\begin{tabular}{|c|c|}
\hline Designation & Sequence and modifications \\
\hline PMP22 for & $5^{\prime}-$ TGTCCAGGCCACCATGAT $-3^{`}$ \\
\hline PMP22 rev & 5'-GAAGAGTTGGCAGAAGAACAGG-3` \\
\hline PMP22 TaqMan probe & $\begin{array}{l}\text { 5'6-FAM- CTGTCGATCATCTTCAG- } \\
\text { CATTCTGTCTCTG -3'BHQ1 }\end{array}$ \\
\hline HSA for & $5^{\circ}$ - GTTGCATGAGAAAACGCCA - $3^{\circ}$ \\
\hline HSA rev & $5^{\circ}-$ GGTCGCCTGTTCACCAAG -3` \\
\hline HSA TaqMan probe & $\begin{array}{l}\text { 5'HEX-AAGTGACAGAGTCACCAAAT- } \\
\text { GCTGCACA -3’BHQ1 }\end{array}$ \\
\hline PMP22 exon 1A for & $5^{\prime}-$ ATATCCCAGCATTGGACCAG -3‘ \\
\hline PMP22 exon 1A rev & $5^{\prime}$ - ATCACCCAGAGGCACAGTTT -3‘ \\
\hline PMP22 exon 2 for & 5'- AGTGCGTTCGGCCTCA - $3^{c}$ \\
\hline PMP22 exon 2 rev & $5^{c}$ - GAACCCAGATGGGGAAGG -3` \\
\hline PMP22 exon 3 for & $5^{c}-$ TCССТСССТСССТGACTC - $3^{c}$ \\
\hline PMP22 exon 3 rev & $5^{\prime}$ - GACAAGCTCATGGAGCACAA -3‘ \\
\hline PMP22 exon 4 for & $5^{c}$ - ATGGCCAGCTCTCCTAACC - $3^{`}$ \\
\hline PMP22 exon 4 rev & $5^{\prime}$ - ATCATTCCGCAGACTTGGAT - $3^{\prime}$ \\
\hline PMP22 exon 5 for & 5'- GCTCTGCCATGGACTCTCC -3` \\
\hline PMP22 exon 5 rev & $5^{\prime}$ - CCCTTCCCTATGTACGCTCA -3‘ \\
\hline
\end{tabular}

probe, $30 \mathrm{ng}$ of template DNA. In every assay, three healthy controls and one non-template control were included. The reactions were performed by means of the ABI 7900HT Fast Real-Time PCR System (Applied Biosystems) instrument, using the following thermal conditions: initial denaturation for $2 \mathrm{~min}$ at $95^{\circ} \mathrm{C}$ followed by 40 cycles of $15 \mathrm{~s}$ denaturation at $95^{\circ} \mathrm{C}$ and $1 \mathrm{~min}$ annealing/polymerization at $60^{\circ} \mathrm{C}$.

Acquired data was analysed by the ABI Sequence Detection Software version 2.1 and Microsoft Excel. Reaction wells with obvious PCR failure were excluded from the analysis and relative PMP22 copy number was evaluated only in samples with at least 3 successful amplifications. Uniform baseline and threshold settings were used for samples run together. Subsequently, the mean $\mathrm{C}_{\mathrm{T}}$ (threshold cycle) values of quadruplicates were calculated for each unknown sample and used for the calculation of gene dosage of PMP22, utilizing the comparative $C_{T}$ method (Livak 1997). The formula

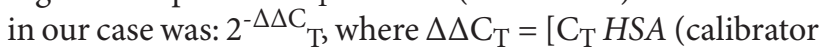
sample) $-\mathrm{C}_{\mathrm{T}} P M P 22$ (calibrator sample) $]-\left[\mathrm{C}_{\mathrm{T}} H S A\right.$ (patient sample) $-\mathrm{C}_{\mathrm{T}}$ PMP22 (patient sample)]. Results of $0.5,1$ and 1.5 indicated deletion, normal copy number and duplication of PMP22, respectively. We used the mean of $\mathrm{C}_{\mathrm{T}}$ values of the three healthy controls as the calibrator sample.

\section{Mutation screening}

Mutation screening of samples was accomplished by denaturing high performance liquid chromatography (dHPLC). The appropriate DNA fragments for dHPLC analysis were prepared by PCR, namely in five reactions which amplified PMP22 exons 1A, 2, 3, 4 and 5 and their surrounding sequences (primer sequences are listed in Table 1). PCR amplifications were carried out using the XP cycler (Bioer) in a final volume of $30 \mu \mathrm{l}$, the reaction mixture contained: 10 mM Tris- $\mathrm{HCl}$ (pH 9.5), $5 \mathrm{mM} \mathrm{MgCl}_{2}, 1.5 \mathrm{mM} \mathrm{KCl}, 0.17 \mathrm{~g} / \mathrm{l}$ BSA, $0.1 \%$ Triton X-100, $200 \mu \mathrm{M}$ of each dNTP (GeneCraft), 0.6 U BioTherm Taq DNA Polymerase (GeneCraft), $1250 \mathrm{nM}$ forward/reverse primers for the desired exon and $50 \mathrm{ng}$ of template DNA. Thermal conditions appropriate for amplification of all exons were: initial denaturation for $2 \mathrm{~min}$ at $95^{\circ} \mathrm{C}$ followed by 40 cycles of $15 \mathrm{~s}$ denaturation at $95^{\circ} \mathrm{C}$, $15 \mathrm{~s}$ annealing at $60.5^{\circ} \mathrm{C}$ and $30 \mathrm{~s}$ polymerization at $72^{\circ} \mathrm{C}$ and final polymerization for $5 \mathrm{~min}$ at $72^{\circ} \mathrm{C}$. The acquired products were subsequently heteroduplexed by heating at $95^{\circ} \mathrm{C}$ and slow cooling and analysed by the WAVE System $3500 \mathrm{HT}$ (Transgenomic). Temperature and acetonitrile gradient settings were individual for each amplicon. Acetonitrile gradient settings were applied as suggested by the Navigator Software (Transgenomic), while analysis temperatures were set manually: $60.8^{\circ} \mathrm{C}$ and $62.7^{\circ} \mathrm{C}$ for exon $1 \mathrm{~A}, 65.4^{\circ} \mathrm{C}$ for exon $2,59.6^{\circ} \mathrm{C}$ and $61^{\circ} \mathrm{C}$ for exon $3,60.1^{\circ} \mathrm{C}$ and $60.6^{\circ} \mathrm{C}$ for exon 4 and $63.4^{\circ} \mathrm{C}$ for exon 5. Data analysis was performed by the Navigator Software. 


\section{DNA sequence analysis}

For sequencing of samples with aberrant dHPLC profile the BigDye Terminator v1.1 Cycle Sequencing Kit (Applied Biosystems) and the ABI PRISM ${ }^{\bullet} 3100$ Genetic Analyzer (Applied Biosystems) were used. Obtained sequences were analysed by Sequencing Analysis Software version 5.4 (Applied Biosystems) and Chromas Lite version 2.01 and subsequently compared to Ensembl reference sequence ENSG00000109099 (GRCh37, chromosome 17, bases 15132495-15169244) using BLAST sequence alignment software to locate/identify the underlying mutations or polymorphisms.

\section{Results}

Validation of the real time PCR method optimized for PMP22 copy number determination was the initial step of our study, prior to patient testing. Validation was accomplished by evaluation of 13 samples with confirmed CMT1A duplication, 2 samples with confirmed HNPP deletion and 110 samples of healthy individuals. Obtained value ranges for the three groups of samples were as follows: $0.624-0.626$ for samples with deletion, $0.758-1.24$ for samples of healthy individuals and 1.356-1.546 for samples with duplication. On the basis of these results, values below 0.65 were assigned to HNPP patients, values between $0.75-1.25$ to healthy individuals and values above 1.35 to CMT1A patients. The value ranges of distinct groups were not overlapping, showing the feasibility of the method to determine PMP22 copy number.

After method validation, 119 families with CMT and 2 families with HNPP were tested for duplication or deletion. During testing, $\Delta \Delta \mathrm{C}_{\mathrm{T}}$ values outside the designated diagnostic ranges occurred in $4.76 \%$ of the analysed samples. In these cases, the real time assay was repeated using other healthy controls - always giving unambiguous results. Individuals in 40 families out of the 119 exhibited duplication of PMP22. Familial inheritance of the duplication was proven in 31 of these families, while the remaining 9 were either isolated cases or families with only the proband's sample provided. In addition, 6 of the 119 families diagnosed with CMT exhibited a PMP22 deletion. From the two families with HNPP, the deletion was identified in one.

After PMP22 copy number determination, chosen samples from families without duplication or deletion were further screened for other causative mutations in the PMP22 gene. Sequencing of samples with aberrant dHPLC profiles revealed six single base changes as listed in Table 2, from which three had already been published. The known sequence variants are polymorphism c.319+33C $>\mathrm{T}$ in intron 4 (rs3744333), nonsense mutation c.327C $>\mathrm{A}$ (Cys109X) in exon 5 and missense mutation c.353C $>\mathrm{T}$ (Thr118Met) in exon 5 (Roa et al. 1993; Abe et al. 2004; Shy et al. 2006). The newly identified variants are c. $-244 \mathrm{C}>\mathrm{T}$ in the promoter region of exon 1A, missense mutation c.172C $>\mathrm{T}$ (Pro58Ser) in exon 3 and missense mutation c.358A $>\mathrm{G}$ (Arg120Gly) in exon 5 . These sequence variants are at present not listed in the Single Nucleotide Polymorphism Database (dbSNP - accessed 5 October 2011) or the Inherited Peripheral Neuropathies Mutation Database (IPNMDB - last update 17 February 2011).

\section{Discussion}

When compiling published data for comparison with our own results, we realized that only some published papers discuss the frequency of $17 \mathrm{p} 11.2-\mathrm{p} 12$ duplication in the total population of CMT-affected patients. More than the half of the studies found by us assessed the frequency of duplication among well defined cohorts of CMT1 (demyelinating CMT with autosomal dominant inheritance) patients. A few of these studies specified the overall number of CMT patients examined, thus we were able to calculate the frequency of duplication in CMT. The rest, however, showed only data acquired from CMT1 patients. To be able to use the outcomes of these publications we extrapolated their results for the whole CMT population

Table 2. Single nucleotide polymorphisms identified in $P M P 22$ in this study and their respective phenotypes

\begin{tabular}{lll}
\hline SNP designation & Region & Phenotype \\
\hline c. $-244 \mathrm{C}>\mathrm{T}$ & promoter of exon 1A & polymorphism \\
c.172C $>\mathrm{T}($ Pro58Ser) & exon 3 & polymorphism \\
c. $319+33 \mathrm{C}>\mathrm{T}(\mathrm{rs} 3744333)$ & intron 4 & polymorphism \\
c.327C $>\mathrm{A}(\mathrm{Cys} 109 \mathrm{X})$ & exon 5 & CMT1 (heterozygotes) \\
c.353C $>\mathrm{T}($ Thr118Met) & exon 5 & HNPP-like neuropathy (heterozygotes), CMT1 (hemizygotes), \\
c.358A $>\mathrm{G}($ Arg120Gly) & exon 5 & CMT2 (homozygotes)
\end{tabular}

${ }^{\star}$ Abe et al. 2004; ${ }^{* *}$ Roa et al. 1993, Shy et al. 2006. 
Table 3. Frequencies of CMT1A duplication among CMT patients in various populations

\begin{tabular}{|c|c|c|c|c|c|c|c|}
\hline & \multicolumn{2}{|c|}{$\begin{array}{l}\text { Unrelated } \\
\text { patients }\end{array}$} & \multirow{2}{*}{$\begin{array}{l}\text { Duplications } \\
\text { found }\end{array}$} & \multirow{2}{*}{$\begin{array}{c}\text { Frequency of } \\
\text { duplication } \\
\text { in CMT1 }(\%)\end{array}$} & \multirow{2}{*}{$\begin{array}{c}\text { Extrapolated } \\
\text { frequency of } \\
\text { duplication in } \\
\text { CMT }(\%)^{*}\end{array}$} & \multirow{2}{*}{$\begin{array}{l}\text { Frequency } \\
\text { of dupli- } \\
\text { cation in } \\
\text { CMT (\%) }\end{array}$} & \multirow{2}{*}{ References } \\
\hline & CMT1 & CMT & & & & & \\
\hline Australia & - & 224 & 136 & - & - & 60.71 & (Nicholson 1999) \\
\hline China & 32 & - & 20 & 62.50 & $37.50-43.75$ & - & (Song et al. 2006) \\
\hline European collaborative study & 819 & - & 579 & 70.70 & $42.42-49.49$ & - & (Nelis et al. 1996) \\
\hline Finland & - & 122 & 64 & - & - & 52.46 & (Silander et al. 1998) \\
\hline Italy & 170 & - & 98 & 57.65 & $34.59-40.35$ & - & (Mostacciuolo et al. 2001) \\
\hline $\operatorname{Japan}^{\dagger}$ & 128 & 217 & 40 & 31.25 & - & 18.43 & (Numakura et al. 2002) \\
\hline $\operatorname{Japan}^{\dagger}$ & 227 & 354 & 53 & 23.35 & - & 14.97 & (Abe et al. 2011) \\
\hline Korea & 28 & 57 & 15 & 53.57 & - & 26.32 & (Choi et al. 2004) \\
\hline Norway & - & 81 & 11 & - & - & 13.58 & (Braathen et al. 2011) \\
\hline Poland & - & 179 & 51 & - & - & 28.49 & (Kabzinska et al. 2009) \\
\hline Russia & 109 & 174 & 59 & 54.13 & - & 33.91 & (Mersiyanova et al. 2000) \\
\hline Slovenia & 36 & - & 29 & 80.56 & $48.33-56.39$ & - & (Leonardis et al. 1998) \\
\hline Spain & - & 133 & 86 & - & - & 64.66 & (Bort et al. 1997) \\
\hline Taiwan & 57 & - & 33 & 57.89 & $34.74-40.53$ & - & (Lee et al. 2004) \\
\hline The Netherlands/Germany & - & 396 & 109 & - & - & 27.52 & (Janssen et al. 1997) \\
\hline $\mathrm{USA}^{\dagger \dagger}$ & 63 & 75 & 43 & 68.25 & - & 57.33 & (Wise et al. 1993) \\
\hline $\mathrm{USA}^{\dagger \dagger}$ & - & 152 & 79 & - & - & 51.97 & (Boerkoel et al. 2002) \\
\hline Average & & & & 55.98 & 39.5 & & \\
\hline Slovakia & 113 & - & 40 & - & - & 35.40 & (present study) \\
\hline
\end{tabular}

In cases where multiple studies were focused on one population (marked by ${ }^{\dagger}$ and ${ }^{\dagger \dagger}$ ), the average values of the outcomes of these studies were used in Average calculation to avoid distortion of its value. For the same reason, average values of respective extrapolated frequency ranges were used in Average calculation; ${ }^{*} 60-70 \%$ of frequency in CMT1.

based on the frequency of CMT1, which is estimated to account for $60-70 \%$ of CMT cases (Shy et al. 2005; Szigeti et al. 2006). Duplication frequencies of different populations obtained after this manner are presented in Table 3.

Quantitative real time PCR analysis of PMP22 copy number in our sample set identified the duplication in $35.40 \%$ of families (40/113). This outcome fits well into the frequency ranges obtained in other studies (see Table 3), although it is somewhat less than the average. Familial occurrence of duplication was proven in $77.50 \%$ of cases $(31 / 40)$, while in $20 \%$ of cases $(8 / 40)$ only the probands sample was available and the family records had no indication of CMT phenotype in relatives. In one family, de novo origin of duplication was confirmed. If we consider the 8 probands with negative family history as sporadic cases, the share of de novo CMT1A duplication on sporadic CMT cases is at least $11.1 \%(1 / 9)$.

The frequencies of duplication and deletion of the $1.5 \mathrm{Mb}$ region mapping to chromosome 17p11.2-12 should be equal according to the fact that these mutations are reciprocal end products of the same crossing-over event. A large epidemiological study of HNPP by Meretoja et al. (1997) already confirmed the equal prevalence of the two mutations. However, most studies report considerably fewer cases of deletion than duplication and anticipate this to be caused by under diagnosis of deletion due to its mild phenotype. We had only 2 HNPP families in our sample set, which means that HNPP is considerably underdiagnosed in Slovakia. Nevertheless, PMP22 copy number determination identified a total of 7 families with deletion, thus the ratio of deletion to duplication is 1 to 5.7. This difference in the number of detected deletions and duplications is similar to the outcome of a European collaborative study by Nelis et al. (1996), although there are publications that reported markedly higher and markedly lower ratios (Silander et al. 1998; Kabzinska et al. 2009).

In the case of the 6 CMT families with identified HNPP deletion, we also considered the possibility of the presence of recessive PMP22 mutations causing CMT phenotype in the hemizygous state, but this alternative was ruled out by sequencing which didn't reveal such mutations (Numakura et al. 2000; Shy et al. 2006). In all of these cases, except one, the family history was negative, thus diagnosis was based on the probands phenotype alone. Five of the probands 
were between the age of 8 and 23, which is most probably not enough time to develop symmetric polyneuropathy. Therefore we presume that these patients were misdiagnosed simply because their physicians were not familiar with HNPP. This clearly emphasizes the need to increase awareness of HNPP in the Slovak medical community and shows the importance of molecular testing in the establishment of reliable diagnosis of inherited peripheral neuropathies.

Heterozygous point mutation c.327C $>$ A (Cys109X) was identified in 3 patients from one family - in the father and his two sons. The father (age 36) was found to be a compound heterozygote who also harboured the mutation c.358A $>$ G (Arg120Gly). He demonstrated symptoms since birth and developed severe neuropathy characterized by atrophy of muscles below the knees, decreased tendon reflexes, hammer toes, bilateral pes cavus and severe peripheral neurologic lesions determined by electromyography (both demyelinating and axonal). Examination of the older son (age 6) revealed diffuse peripheral muscle atrophy, inability to stimulate the peroneal nerve and a mild paraparetic gait. The younger son (age 3) showed limited dorsiflection of the feet, decreased patellar reflexes and the inability to step on his heels leading to pathological gait. The mutation Arg120Gly hasn't been described yet, but owing to the masking effect of Cys109X it's impossible to tell whether it is a disease-causing mutation or a benign polymorphism. The severe clinical symptoms of the father carrying both mutations and the fact that he was affected since birth support the possibility that Arg120Gly has a pathogenic effect. On the other hand, a previous study focusing on the mutation Cys109X found high variability of clinical symptoms of CMT1, even among patients from one family (age of onset 2-16 years) (Abe et al. 2004). This implies that Arg120Gly could also be a benign polymorphism, in which case our patient would demonstrate another, more severe phenotype of Cys109X not described before.

Mutation c.353C $>\mathrm{T}$ (Thr118Met) causes a partial lossof-function of the PMP22 protein that leads to different phenotypes depending on the presence of other alleles. Heterozygotes develop a HNPP-like neuropathy, homozygotes develop CMT2, hemizygotes develop CMT1 and if coupled with the CMT1A duplication, it should cause a milder phenotype than that typically seen in patients with duplication (Roa et al. 1993; Shy et al. 2006). We found this mutation in two patients from one family, who also harboured the duplication, but unfortunately we were unable to obtain reliable clinical data on these patients, thus we can neither support nor oppose the phenotype-genotype correlations presented by previous studies.

Sequence variants c. $-244 \mathrm{C}>\mathrm{T}$ and c. $172 \mathrm{C}>\mathrm{T}$ (Pro58Ser) haven't been described to date, but they don't segregate with the CMT1 phenotype in respective families, which indicates that these are benign polymorphisms and not causative mutations. Polymorphism c. $319+33 \mathrm{C}>\mathrm{T}$ in contrast to other single nucleotide polymorphisms detected in this study was found to have a relatively high frequency in our set of CMT patients. It was identified in 8 index cases (heterozygotes) out of 79 , which is $10.13 \%$.

In spite of the considerably heterogeneous genetic background of inherited peripheral neuropathies, the mutation frequency of involved genes is fairly consistent in numerous populations. Accordingly, suggested diagnostic algorithms for effective detection of CMT and related inherited peripheral neuropathies are applicable in clinical laboratories worldwide. The most common mutations causing demyelinating neuropathy are duplication of $P M P 22$ followed by $\mathrm{mu}-$ tations in GJB1 (gap junction protein, beta 1, $32 \mathrm{kDa}$ ), $M P Z$ (myelin protein zero) and point mutations in PMP22. In axonal neuropathy, mutations of $M F N 2$ (mitofusin 2), GJB1 and $M P Z$ are the most frequent. In HNPP, deletion of PMP22 is the major cause but occasionally also point mutations of PMP22 are found to be responsible. Mutation screening of these genes enables the establishment of molecular diagnosis in over $80 \%$ of demyelinating neuropathies, $20-30 \%$ of axonal neuropathies and over $90 \%$ of HNPP cases (Banchs et al. 2009; Szigeti and Lupski 2009). None of the above mentioned genes were studied in the Slovak population before, but as expected, our results indicate that the relative frequencies of mutations of these genes are similar to that seen in the global population. Accordingly, in the next stage of our research we plan to accomplish the mutation screen of GJB1, MPZ, NEFL (neurofilament, light polypeptide) and EGR2 (early growth response protein 2) genes of patients with undetected molecular cause of disease to determine the correct diagnosis and assign appropriate therapy.

Mutation analysis of PMP22 in Slovak patients with Charcot-Marie-Tooth disease and related inherited peripheral neuropathies revealed the underlying mutation in 39.67\% of families. The prevailing mutations, as expected, were CMT1A duplication and HNPP deletion, confirming the role of PMP22 copy number determination as the first choice diagnostic approach in the establishment of differential diagnosis in inherited demyelinating neuropathies. The relative frequency of CMT1A duplication, HNPP deletion and other PMP22 point mutations is lower in the Slovak clinical population than the global average, but our results correlate well with the outcomes of numerous studies. This supports the observation that the occurrence of these mutations is alike in the majority of developed countries.

Acknowledgement. We would like to thank Dr. Pavel Seeman (University Hospital Motol, Charles University, Prague, Czech Republic) for providing us with control samples of CMT duplication and HNPP deletion. Furthermore, we thank Ivan Kosik, Zsolt Voros and Ray Marshall for English revision and helpful 
comments on the manuscript. This work was supported by grants from the Slovak Grant Agency VEGA (1/0602/08), Ministry of Education of the Slovak Republic (AV 4/2029/08) and Comenius University (UK /210/2007 and UK /290/2008).

\section{References}

Abe K. T., Lino A. M. M., Hirata M. T. A., Pavanello R. C., Brotto M. W., Marchiori P. E., Zatz M. (2004): A novel stop codon mutation in the PMP22 gene associated with a variable phenotype. Neuromuscul. Disord. 14, 313-320 http://dx.doi.org/10.1016/j.nmd.2004.01.007

Abe A., Numakura C., Kijima K., Hayashi M., Hashimoto T., Hayasaka K. (2011): Molecular diagnosis and clinical onset of Charcot-Marie-Tooth disease in Japan. J. Hum. Genet. 56, 364-368 http://dx.doi.org/10.1038/jhg.2011.20

Baechner D., Liehr T., Hameister H., Altenberger H., Grehl H., Suter U., Rautenstrauss B. (1995): Widespread expression of the peripheral myelin protein-22 gene (PMP22) in neural and non-neural tissues during murine development. J. Neurosci. Res. 42, 733-741 http://dx.doi.org/10.1002/jnr.490420602

Banchs I., Casasnovas C., Albertí A., De Jorge L., Povedano M., Montero J., Martínez-Matos J. A., Volpini V. (2009): Diagnosis of Charcot-Marie-Tooth Disease. J. Biomed. Biotechnol. 2009, 985415 http://dx.doi.org/10.1155/2009/985415

Barisic N., Claeys K. G., Sirotković-Skerlev M., Löfgren A., Nelis E., De Jonghe P., Timmerman V. (2008): Charcot-Marie-Tooth disease: a clinico-genetic confrontation. Ann. Hum. Genet. 72, 416-441 http://dx.doi.org/10.1111/j.1469-1809.2007.00412.x

Boerkoel C. F., Takashima H., Garcia C. A., Olney R. K., Johnson J., Berry K., Russo P., Kennedy S., Teebi A. S., Scavina M., Williams L. L., Mancias P., Butler I. J., Krajewski K., Shy M., Lupski J. R. (2002): Charcot-Marie-Tooth Disease and Related Neuropathies: Mutation Distribution and Genotype-Phenotype Correlation. Ann. Neurol. 51, 190-201 http://dx.doi.org/10.1002/ana.10089

Bort S., Nelis E., Timmerman V., Sevilla T., Cruz-Martínez A., Martínez F., Millán J. M., Arpa J., Vílchez J. J., Prieto F., Van Broeckhoven C., Palau F. (1997): Mutational analysis of the MPZ, PMP22 and Cx32 genes in patients of Spanish ancestry with Charcot-Marie-Tooth disease and hereditary neuropathy with liability to pressure palsies. Hum. Genet. 99, 746-754 http://dx.doi.org/10.1007/s004390050442

Braathen G. J., Sand J. C., Lobato A., Høyer H., Russell M. B. (2011): Genetic epidemiology of Charcot-Marie-Tooth in the general population. Eur. J. Neurol. 18, 29-48 http://dx.doi.org/10.1111/j.1468-1331.2010.03037.x

Chance P. F., Alderson M. K., Leppig K. A., Lensch M. W., Matsunami N., Smith B., Swanson P. D., Odelberg S. J., Disteche C. M., Bird T. D. (1993): DNA deletion associated with hereditary neuropathy with liability to pressure palsies. Cell 72, 143-151 http://dx.doi.org/10.1016/0092-8674(93)90058-X
Choi B. O., Lee M. S., Shin S. H., Hwang J. H., Choi K. G., Kim W. K., Sunwoo I. N., Kim N. K., Chung K. W. (2004): Mutational Analysis of PMP22, MPZ, GJB1, EGR2 and NEFL in Korean Charcot-Marie-Tooth Neuropathy Patients. Hum. Mutat. 24, 185-186. Erratum in: Hum. Mutat. 24, 350 http://dx.doi.org/10.1002/humu.9261

D’Urso D., Müller H. W. (1997): Ins and outs of peripheral myelin protein-22: mapping transmembrane topology and intracellular sorting. J. Neurosci. Res. 49, 551-562

http://dx.doi.org/10.1002/(SICI)1097-4547(19970901)49:5<551:: AID-JNR5>3.0.CO;2-A

Emery A. E. (1991): Population frequencies of inherited neuromuscular diseases - a world survey. Neuromuscul. Disord. 1, 19-29 http://dx.doi.org/10.1016/0960-8966(91)90039-U

Felice K. J., Poole R. M., Blaivas M., Albers J. W. (1994): Hereditary neuropathy with liability to pressure palsies masquerading as slowly progressive polyneuropathy. Eur. Neurol. 34, 173-176 http://dx.doi.org/10.1159/000117033

Garcia C. A., Malamut R. E., England J. D., Parry G. S., Liu P., Lupski J. R. (1995): Clinical variability in two pairs of identical twins with Charcot-Marie-Tooth disease type 1A duplication. Neurology 45, 2090-2093

Gouide R., LeGuern E., Gugenheim M., Tardieu S., Maisonobe T., Léger J. M., Vallat J. M., Agid Y., Bouche P., Brice A. (1995): Clinical, electrophysiologic, and molecular correlations in 13 families with hereditary neuropathy with liability to pressure palsies and a chromosome 17p11.2 deletion. Neurology 45, 2018-2023

Harding A. E., Thomas P. K. (1980): The clinical features of hereditary motor and sensory neuropathy types I and II. Brain 103, 259-280 http://dx.doi.org/10.1093/brain/103.2.259

Janssen E. A., Kemp S., Hensels G. W., Sie O. G., de Die-Smulders C. E., Hoogendijk J. E., de Visser M., Bolhuis P. A. (1997): Connexin 32 gene mutations in X-linked dominant CharcotMarie-Tooth disease (CMTX1). Hum. Genet. 99, 501-505 http://dx.doi.org/10.1007/s004390050396

Kabzinska D., Pierscinska J., Kochanski A. (2009): Screening of the 17p11.2-p12 region in a large cohort of patients with Charcot-Marie-Tooth (CMT) disease or hereditary neuropathy with liability to pressure palsies (HNPP). J. Appl. Genet. 50, 283-288 http://dx.doi.org/10.1007/BF03195684

Kumar N., Cole J., Parry G. J. (1999): Variability of presentation in hereditary neuropathy with liability to pressure palsy results in underrecognition. Ann. N. Y. Acad. Sci. 883, 344-350 http://dx.doi.org/10.1111/j.1749-6632.1999.tb08596.x

Kunkel L. M., Smith K. D., Boyer S. H., Borgaonkar D. S., Wachtel S. S., Miller O. J., Breg W. R., Jr. Jones H. W., Rary J. M. (1977): Analysis of human Y-chromosome-specific reiterated DNA in chromosome variants. Proc. Natl. Acad. Sci. U.S.A. 74, 1245-1249 http://dx.doi.org/10.1073/pnas.74.3.1245

Lee Y. C., Soong B. W., Lin K. P., Lee H. Y., Wu Z. A., Kao K. P. (2004): Myelin protein zero gene mutations in Taiwanese patients with Charcot-Marie-Tooth disease type 1. J. Neurol. Sci. 219, 95-100 http://dx.doi.org/10.1016/j.jns.2003.12.009 
Leonardis L., Zidar J., Ekici A., Peterlin B., Rautenstrauss B. (1998): Autosomal dominant Charcot-Marie-Tooth disease type 1A and hereditary neuropathy with liability to pressure palsies: detection of the recombination in Slovene patients and exclusion of the potentially recessive Thr118Met PMP22 point mutation. Int. J. Mol. Med. 1, 495-501

Li J., Krajewski K., Shy M. E., Lewis R. A. (2002): Hereditary neuropathy with liability to pressure palsy: the electrophysiology fits the name. Neurology 58, 1769-1773

Livak K. J. (1997): Comparative Ct method. In: ABI Prism 7700 Sequence Detection System, User Bulletin no. 2. PE Applied Biosystems

Lupski J. R., Garcia C. A., Parry G. J., Patel P. I. (1991): CharcotMarie-Tooth polyneuropathy syndrome: clinical, electrophysiological, and genetic aspects. In: Current Neurology. (Ed. S. Appel), pp. 1-25, Mosby-Year Book, Chicago

Meretoja P., Silander K., Kalimo H., Aula P., Meretoja A., Savontaus M.-L. (1997): Epidemiology of hereditary neuropathy with liability to pressure palsies (HNPP) in south western Finland. Neuromuscul. Disord. 7, 529-532 http://dx.doi.org/10.1016/S0960-8966(97)00100-4

Mersiyanova I. V., Ismailov S. M., Polyakov A. V., Dadali E. L., Fedotov V. P., Nelis E., Löfgren A., Timmerman V., van Broeckhoven C., Evgrafov O. V. (2000): Screening for Mutations in the Peripheral Myelin Genes PMP22, MPZ and Cx32 (GJB1) in Russian Charcot-Marie-Tooth Neuropathy Patients. Hum. Mutat. 15, 340-347. Erratum in: Hum. Mutat. 16, 175

http://dx.doi.org/10.1002/(SICI)1098-1004(200004)15:4<340:: AID-HUMU6>3.0.CO;2-Y

Mostacciuolo M. L., Righetti E., Zortea M., Bosello V., Schiavon F., Vallo L., Merlini L., Siciliano G., Fabrizi G.M., Rizzuto N., Milani M., Baratta S., Taroni F. (2001): Charcot-Marie-Tooth disease type I and related demyelinating neuropathies: mutation analysis in a large cohort of italian families. Hum. Mutat. 18, 32-41 http://dx.doi.org/10.1002/humu.1147

Nelis E., Van Broeckhoven C., De Jonghe P., Löfgren A., Vandenberghe A., Latour P., Le Guern E., Brice A., Mostacciuolo M. L., Schiavon F., Palau F., Bort S., Upadhyaya M., Rocchi M., Archidiacono N., Mandich P., Bellone E., Silander K., Savontaus M. L., Navon R., Goldberg-Stern H., Estivill X., Volpini V., Friedl W., Gal A., et al. (1996): Estimation of the mutation frequencies in Charcot-Marie-Tooth disease type 1 and hereditary neuropathy with liability to pressure palsies: a European collaborative study. Eur. J. Hum. Genet. 4, 25-33

Nelis E., Timmerman V., De Jonghe P., Van Broeckhoven C., Rautenstrauss B. (1999): Molecular genetics and biology of inherited peripheral neuropathies: a fast-moving field. Neurogenetics 2, 137-148 http://dx.doi.org/10.1007/s100480050074

Nicholson G. A. (1999): Mutation testing in Charcot-Marie-Tooth neuropathy. Ann. N. Y. Acad. Sci. 883, 383-388 http://dx.doi.org/10.1111/j.1749-6632.1999.tb08599.x

Nicholson G., Myers S. (2006): Intermediate forms of CharcotMarie-Tooth neuropathy: a review. Neuromolecular Med. 8, 123-130 http://dx.doi.org/10.1385/NMM:8:1:123
Numakura C., Lin C., Oka N., Akiguchi I., Hayasaka K. (2000): Hemizygous mutation of the peripheral myelin protein 22 gene associated with Charcot-Marie-Tooth disease type 1. Ann. Neurol. 47, 101-103 http://dx.doi.org/10.1002/1531-8249(200001)47:1<101::AID-ANA16>3.0.CO;2-2

Numakura C., Lin C., Ikegami T., Guldberg P., Hayasaka K. (2002): Molecular Analysis in Japanese Patients With Charcot-MarieTooth Disease: DGGE Analysis for PMP22, MPZ, and Cx32/ GJB1 Mutations. Hum. Mutat. 20, 392-398 http://dx.doi.org/10.1002/humu.10134

Pareyson D., Scaioli V., Taroni F., Botti S., Lorenzetti D., Solari A., Ciano C., Sghirlanzoni A. (1996): Phenotypic heterogeneity in hereditary neuropathy with liability to pressure palsies associated with chromosome 17p11.2-12 deletion. Neurology 46, 1133-1137

Raeymaekers P., Timmerman V., Nelis E., De Jonghe P., Hoogendijk J. E., Baas F., Barker D. F., Martin J. J., De Visser M., Bolhuis P. A., et al. (1991): Duplication in chromosome 17p11.2 in Charcot-Marie-Tooth neuropathy type 1a (CMT 1a). The HMSN Collaborative Research Group. Neuromuscul. Disord. 1, 93-97 http://dx.doi.org/10.1016/0960-8966(91)90055-W

Roa B. B., Garcia C. A., Pentao L., Killian J. M., Trask B. J., Suter U., Snipes G. J., Ortiz-Lopez R., Shooter E. M., Patel P. I., Lupski J. R. (1993): Evidence for a recessive PMP22 point mutation in Charcot-Marie-Tooth disease type 1A. Nat. Genet. 5, 189-194 http://dx.doi.org/10.1038/ng1093-189

Saifi G. M., Szigeti K., Snipes G. J., Garcia C. A., Lupski J. R. (2003): Molecular mechanisms, diagnosis, and rational approaches to management of and therapy for Charcot-Marie-Tooth disease and related peripheral neuropathies. J. Investig. Med. 51, 261-283 http://dx.doi.org/10.2310/6650.2003.3716

Sanders C. R., Ismail-Beigi F., McEnery M. W. (2001): Mutations of peripheral myelin protein 22 result in defective trafficking through mechanisms which may be common to diseases involving tetraspan membrane proteins. Biochemistry 40, 9453-9459 http://dx.doi.org/10.1021/bi010894f

Shy M. E., Lupski J. R., Chance P. F., Klein C. J., Dyck P. J. (2005): Hereditary motor and sensory neuropathies. In: Peripheral Neuropathy Vol. I. (Eds. P. J. Dyck, P. K. Thomas and E. H. Lambert), pp. 1623-1658, Elsevier, Philadelphia

Shy M. E., Scavina M. T., Clark A., Krajewski K. M., Li J., Kamholz J., Kolodny E., Szigeti K., Fischer R. A., Saifi G. M., Scherer S. S., Lupski J. R. (2006): T118M PMP22 mutation causes partial loss of function and HNPP-like neuropathy. Ann. Neurol. 59, 358-364 http://dx.doi.org/10.1002/ana.20777

Silander K., Meretoja P., Juvonen V., Ignatius J., Pihko H., Saarinen A., Wallden T., Herrgård E., Aula P., Savontaus M. L. (1998): Spectrum of mutations in finnish patients with CharcotMarie-Tooth disease and related neuropathies. Hum. Mutat. 12, 59-68 http://dx.doi.org/10.1002/(SICI)1098-1004(1998)12:1<59:: AID-HUMU9>3.0.CO;2-A

Skre H. (1974): Genetic and clinical aspects of Charcot-MarieTooth's disease. Clin. Genet. 6, 98-118 
http://dx.doi.org/10.1111/j.1399-0004.1974.tb00638.x

Snipes G. J., Suter U., Welcher A. A., Shooter E. M. (1992): Characterization of a novel peripheral nervous system myelin protein (PMP-22/SR13). J. Cell. Biol. 117, 225-238 http://dx.doi.org/10.1083/jcb.117.1.225

Song S., Zhang Y., Chen B., Zhang Y., Wang M., Wang Y., Yan M., Zou J., Huang Y., Zhong N. (2006): Mutation frequency for Charcot-Marie-Tooth disease type 1 in the Chinese population is similar to that in the global ethnic patients. Genet. Med. 8, 532-535

http://dx.doi.org/10.1097/01.gim.0000232481.96287.89

Szigeti K., Garcia C. A., Lupski J. R. (2006): Charcot-Marie-Tooth disease and related hereditary polyneuropathies: Molecular diagnostics determine aspects of medical management. Genet. Med. 8, 86-92

http://dx.doi.org/10.1097/01.gim.0000200160.29385.73
Szigeti K., Lupski J. R. (2009): Charcot-Marie-Tooth disease. Eur. J. Hum. Genet. 17, 703-710 http://dx.doi.org/10.1038/ejhg.2009.31

Verhagen W. I., Gabreels-Festen A. A., Van Wensen P. J., Joosten E. M., Vingerhoets H. M., Gabreëls F. J., de Graaf R. (1993): Hereditary neuropathy with liability to pressure palsies: a clinical, electroneurophysiological and morphological study. J. Neurol. Sci. 116, 176-184 http://dx.doi.org/10.1016/0022-510X(93)90323-Q

Wise C. A., Garcia C. A., Davis S. N., Heju Z., Pentao L., Patel P. I., Lupski J. R. (1993): Molecular Analyses of Unrelated CharcotMarie-Tooth (CMT) Disease Patients suggest a high frequency of the cmt i a duplication. Am. J. Hum. Genet. 53, 853-863

Received: December 7, 2010

Final version accepted: July 7, 2011 